[Agr. Biol. Chem., Vol. 32, No. 2, p. 203 208, 1968]

\title{
Incorporation of Angustmycin C, a Nucleosidic Antibiotic, into Ribonucleic Acid in Escherichia coli
}

\author{
By Teruhiko Beppu, Masako Nose and Kei Arima \\ Department of Agricultural Chemistry, The University of Tokyo \\ Received August 16, 1967
}

\begin{abstract}
A nucleosidic antibiotic angustmycin $\mathrm{C}$, which is an analogue of adenosine and which has an unusual hexose, psicofuranose, instead of ribose, was confirmed to be incorporated into RNA in Escherichia coli. After incubation of cells with tritiated angustmycin C, small but significant radioactivity was found in RNA fraction. When the RNA was hydrolyzed by an enzyme mixture of snake venom, pancreatic ribonuclease I and alkaline phosphatase, intact angustmycin $\mathrm{C}$ was recovered which indicated incorporation of the antibiotic into the polyribonucleotide chain of RNA.
\end{abstract}

Various antimetabolites of nucleic acid bases or nucleosides have been studied as a tool to investigate biochemistry of nucleic acid or chemotherapeutic agents. Among them, a special class of analogues, such as D-arabinosylcytosine, cordycepin and angustmycin C, which have normal nucleic acid bases linking to unusual sugars was reported to have inhibitory effect on various living cells. Although many investigations have revealed that various nucleic acid antimetabolites replace natural bases in nucleic acid at a considerable extent and produce some functional defect, ${ }^{1}$ incorporation of such nucleosidic analogues into nucleic acid has not yet been thoroughly investigated. Only $\mathrm{D}$-arabinosylcytosine was reported to be incorporated into nucleic acids (RNA and DNA) in leukemic cells. ${ }^{2}$ Angustmycin C (psicofuranine, 9-D-psicofuranosyladenine) is one of such analogues which is isolated from the culture media of Streptomyces hygroscopicus var. angustmyceticus. ${ }^{3 \sim 51}$ It was

1) R. E. Handschumacher and A. D. Welch, "The Nucleic Acid", ed. by E. Chargaff and J. N. Davidson, vol. 3, Academic Press, N. Y., 1960, p. 453.

2) M.Y.Chu and G.A. Fischer, Biochem. Pharmacol., 14, 333 (1965).

3) Y. Hsü, H. Yonehara and H. Ui, J. Antibiotics (Japan), 7A, 113 (1954); H. Sakai, Y. Hsü and F. Ishikawa, ibid., $7 \mathbf{A}, 116$ (1954). suggested by the authors ${ }^{6}$ and others with various organisms that angustmycin $\mathrm{C}$ inhibited the biosynthesis of guanosine-5'-phosphate, which was confirmed in vitro by the fact that the antibiotic strongly inhibited xanthosine- $5^{\prime}$ phosphate aminase. ${ }^{7}$ However, residual inhibitory effect on $\beta$-galactosidase synthesis after removal of angustmycin $C$ seemed to suggest possibility of another mechanism of inhibition such as incorporation of the antibiotic into cellular nucleic acid. In this communication, we report an attempt to reveal that this abtibiotic is incorporated into nucleic acid in Escherichia coli. Using tritiated angustmycin C, small but significant incorporation into RNA was observed.

\section{METHODS AND MATERIALS}

Escherichia coli B-151-9 was used throughout this study. The organism was grown aerobically at $30^{\circ} \mathrm{C}$ in a medium containing $2 \mathrm{~g}$ of glucose, $1 \mathrm{~g}$ of $\left(\mathrm{NH}_{4}\right)_{2} \mathrm{SO}_{4}, 7 \mathrm{~g}$ of $\mathrm{Na}_{2} \mathrm{HPO}_{4} \cdot 2 \mathrm{H}_{2} \mathrm{O}, 2 \mathrm{~g}$ of $\mathrm{KH}_{2} \mathrm{PO}_{4}$, $0.1 \mathrm{~g}$ of $\mathrm{MgSO}_{4} \cdot 7 \mathrm{H}_{2} \mathrm{O}$ and $3 \mathrm{mg}$ of $\mathrm{FeSO}_{4} \cdot 7 \mathrm{H}_{2} \mathrm{O}$ in 1 liter of distilled water.

4) Y. Hsü, J. Antib. (Japan), 11, 244 (1958).

5) W. Schroeder and H. Hoeksema, J. Am. Chem. Soc., 81, 1767 (1959).

6) T. Beppu, M. Nose and K. Arima, Agr. Biol. Chem., 32, 197 (1968).

7) S. Udaka and H.S. Moyed, J. Biol. Chem., 238, 2797 (1963). 
For preparing ${ }^{3} \mathrm{H}$-angustmycin $\mathrm{C}, 250 \mathrm{mg}$ of the antibiotic was tritiated under ${ }^{3} \mathrm{H}_{2}$-gas ( $3 \mathrm{Ci}$ ) for 28 days and purified by cellulose powder chromatography. ${ }^{4}$ ? Specific radioactivity of the purified preparation was $4.1 \times 10^{6} \mathrm{cpm} / \mathrm{mmole}$.

Procedure for fractionation of cell components was carried out according to the method of SchmidtThannhauser. ${ }^{8}$ About $0.5 \mathrm{~g}$ of washed cells were extracted successively twice with $10 \mathrm{ml}$ of cold 50 trichloroacetic acid, twice with $10 \mathrm{ml}$ of ethanol and twice with $10 \mathrm{ml}$ of ethanol-ether $(3: 1)$. The residual cells were suspended in $2 \mathrm{ml}$ of $0.3 \mathrm{~N} \mathrm{KOH}$ and incubated for $15 \mathrm{hr}$ at $37^{\circ} \mathrm{C}$. After adding trichloroacetic acid to a final concentration of $10 \%$, the suspension was centrifuged and the pellet was extracted with $4 \mathrm{ml}$ of $50 \%$ trichloroacetic acid at $90^{\circ} \mathrm{C}$ for $30 \mathrm{~min}$. The hot acid-insoluble residues were dissolved in a Hiamine solution $(\times 10)$. Each extracted fraction was counted for ${ }^{3} \mathrm{H}$ with a liquid scintillation counter. Correction for quenching was made by the inner standard method. Scintillator solution contained $7 \mathrm{~g}$ of PPO, $0.3 \mathrm{~g}$ of POPOP and $100 \mathrm{~g}$ of naphthalene in 1 liter of dioxane.

Ribonucleic acid was extracted by the phenol method.9) The labeled cells were disrupted by sonic oscillation in $0.01 \mathrm{M}$ tris-hydroxymethylaminomethane$\mathrm{HCl}$ (pH 7.4) containing $0.01 \mathrm{M} \mathrm{MgCl}_{2}$, and the homogenates were deproteinized by treatment with water-saturated phenol. In some cases, treatment with 2-methoxyethanol was further performed to remove contamination. RNA was then precipitated by adding ethanol.

Hydrolysis of the RNA preparation by alkali was carried out by $0.4 \mathrm{~N} \mathrm{KOH}$ at $37^{\circ} \mathrm{C}$ for $15 \mathrm{hr}$. Enzymatic hydrolysis was carried out by incubation with the mixture of several enzymes including pancreatic ribonulease I, spleen phosphodiesterase, snake venom phosphodiesterase and alkaline phosphatase $(1 / \mathrm{g} / \mathrm{ml}$ each) at $37 \% \mathrm{C}$ for $15 \mathrm{hr}$. The enzyme protein was removed by adding perchloric acid to final concentration of $50 \%$. The neutralized hydrolyzates were adsorbed on Dowex-1 (formate) columns which were eluted by gradient concentration of formic acid to separate nucleosides and nucleotides. ${ }^{10)}$ Paper chromatography in $n$-butanol containing 1,0 pyridine was

8) C. Schmidt and S.J. Thannhauser, J. Biol. Chem., 161, 83 (1945).

9) K. S. Kirby, Biochem. J., 64405 (1956).

$10)$ B. Hurbert, H. Schmitz, A. F. Brumm and V. R. Potter, J. Biol. Chem., 209, 23 (1954). used to separate adenosine and angustmycin $C$, in which $R f$ values of them were about 0.33 and 0.2 , respectively.

Zonal centrifugation of the RNA in a sucrose density gradient $(3.3 \sim 20 \%)$ was performed according to the procedure described by Britten and Roberts. 11

Assays of $\beta$-galactosidase activity were carried out with the toluenized cell suspensions using O-nitrophenyl- $\beta$-D-galactoside as the substrate. ${ }^{12}$ Growth was measured spectrophotometrically at $550 \mathrm{~m} \mu$.

Total amounts of RNA in the cells were measured by the colorimetric methodi3) after hydrolysis with hot trichloroacetic acid.

Angustmycin $\mathrm{C}$ was a generous gift from Dr. Ōtake. Crystalline alkaline phosphatase from calf mucosa, calf spleen phosphodiesterase, pancreatic ribonuclease I, and snake venom (Crotalus adamanteus) were purchased from the Sigma Chemical Co., St Louis, U.S.A. Thiomethyl- $\beta$-D-galactoside and O-nitrophenyl- $\beta$-Dgalactoside were purchased from the Calbiochem Co., Los Angeles, U.S.A.

\section{RESULTS}

Possible biochemical effect of angustmycin $C$ incorporation

Although main biochemical effect of the antibiotic seemed to be explained by the potent inhibitory effect on xanthosine-5'phosphate aminase which caused severe suppression of nucleic acid synthesis, analysis of inhibitory effect of angustmycin $\mathrm{C}$ on $\beta$ galactosidase synthesis suggested another possible inhibition mechanism.

When $100 \mu \mathrm{g} / \mathrm{ml}$ of angustmycin $\mathrm{C}$ was added to exponentially growing culture of $E$. coli, which had been synthesizing $\beta$-galactosidase in the presence of $10^{-4} \mathrm{M}$ of thiomethylgalactoside as inducer, the enzyme synthesis as well as cell growth was inhibited. After $1 \mathrm{hr}$ incubation with the antibiotic, cells were centrifuged, washed and resuspended in the new medium. The cell growth was resumed soon after removal of the antibiotic while $\beta$-galactosidase synthesis resumed only gradually. Similar

11) R.J. Britten and R. B. Roberts, Science, 131, 32 (1960).

12) K. Wallenfels, M. L. Zarnitz, G. Laule, H. Bender and M. Keser, Biochem. Z., 331, 459 (1959).

13) A. H. Brown, Arch. Biochem., 11, 269 (1946). 
phenomenon was also observed when guanosine, a potent competiter for angustmycin $\mathrm{C}$, was added to remove the inhibition due to angustmycin $\mathrm{C}$. The residual inhibitory effect was clearly shown by plotting enzyme activities against cell growth after addition of guanosine (Fig. 1). Since inhibitory effect of angustmycin $\mathrm{C}$ on xanthosine-5'-phosphate aminase was rapidly recovered by these treatments, the residual inhibitory effect seemed to suggest the possibility that some functional defect not recovered after removal of the antibiotic was made during the incubation with angustmycin C. One of the possible explanation may be that the defect was resulted from the incorporation of angustmycin $\mathrm{C}$ into nucleic acid.

Starting from such considerations on the inhibitory mechanisms, we tried to confirm that angustmycin $\mathrm{C}$ was incorporated into cellular nucleic acid in $E$. coli.

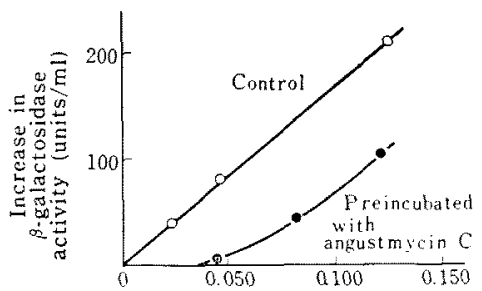

Cell growth after the addition of guanosine (OD)

Fyg. 1. The Residual Inhibitory Effect of Preincubation with Angustmycin $\mathrm{C}$ on $\beta$-Galactosidase Synthesis in E. coli.

Thiomethylgalactoside $\left(10^{-4} \mathrm{M}\right)$ was added to the growing $E$. coli cultures at $O D_{550 m s}=0.200$. After $30 \mathrm{~min}$ growing at $30^{\circ} \mathrm{C}, 100 \mathrm{~kg} / \mathrm{ml}$ of angustmycin $\mathrm{C}$ was added and incubated for another $60 \mathrm{~min}$ at $30^{\circ} \mathrm{C}$. Then $200 \mu \mathrm{g} / \mathrm{ml}$ of guanosine was added, and resumptions of growth and $\beta$-galactosidase synthesis were measured. Addition of the antibiotic was omitted in the control experiment.

Distribution of radioactivity in the cells incubated with tritiated angustmycin $\mathrm{C}$

When ${ }^{3} \mathrm{H}$-angustmycin $\mathrm{C}$ was added to exponentially growing culture of $E$. coli at a concentration of $100 \mu \mathrm{g} / \mathrm{ml}$, rapid incorporation of radioactivity into the cold acid-insoluble frac-

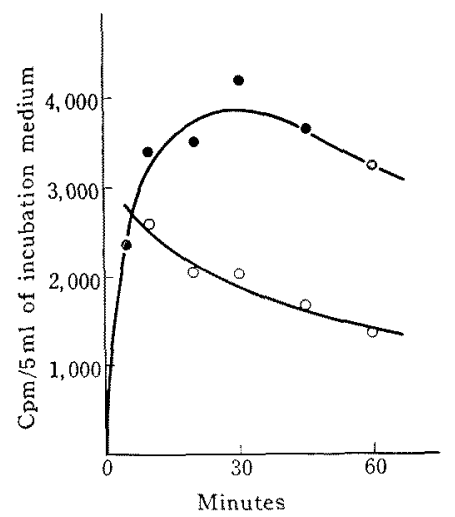

FIG. 2. Incorporation of Radioactivity in the Cells during Incubation with $100 \mu \mathrm{g} / \mathrm{ml}$ of ${ }^{3} \mathrm{H}$-Angustmycin $\mathbf{C}$.

$-1-$ Radioactivity in RNA fraction
- - Radioactivity in the cold acid-soluble
fraction

tion was observed (Fig. 2). After the growth with ${ }^{3} \mathrm{H}$-angustmycin $\mathrm{C}$ for $60 \mathrm{~min}$, cells were harvested and washed twice with $0.8 \% \mathrm{NaCl}$. Fractionation of the cell components was carried out as described in the methods. It was observed that about $2.30^{\circ}$ of the added antibiotic was taken up by the cells and that the largest amount of radioactivity in the cells was present in the RNA fraction, although considerable amount was present in the cold acid-extractable fraction and the ethanol-etherextractable fraction. (Table I).

TABLE I. DISTRIBUTION OF RADIOACTIVITY IN E. coli Cells INCUBATED With 3H-ANGUSTMYCIN $\mathrm{G}$

$5.0 \mathrm{mg}$ of angustmycin $\mathrm{C}$ (about $7 \times 10^{7} \mathrm{cpm}$ ) was added to $50 \mathrm{ml}$ of growing culture of E. coli. Dry weight of harvested cells fractionated was $39 \mathrm{mg}$. Total amount of RNA was measured to be $7.7 \mathrm{mg}$.

\section{Fractions}

Cold acid-soluble (nucleosides and nucleotides)

Ethanol-ether-soluble (lipid)

Alkali-soluble (RNA)

Hot acid-soluble (DNA)

Hot acid-insoluble (protein) $\mathrm{cpm}$

$3.23 \times 10^{5}$

$3.57 \times 10^{5}$

$5.82 \times 10^{5}$

$0.88 \times 10^{5}$

$0.41 \times 10^{5}$
9

23.2

25.6

41.9

6.3

2.9 
Incorporation of radioactivity of angustmycin $C$ into RNA

In order to ascertain incorporation of radioactivity into nucleic acid, RNA was isolated by the phenol treatments of the disrupted cells and ethanol precipitation. As shown in Table II, specific radioactivities of the RNA preparations did not decrease but slightly increase during these treatments. When the purified RNA preparation was treated with pancreatic ribonuclease $I$, it was observed that almost all radioactivities became soluble in $5 \%$ trichloroacetic acid rapidly.

Purified RNA preparation was also examined by zonal centrifugation in a sucrose density gradient. Three bands were observed, two of which were ribosomal RNA and one was

TABle II. PURIfication of LABELEd RNA From E. coli Cells InCUBATEd With ${ }^{3} \mathrm{H}$-ANGUSTMYCIN $\mathrm{C}$

\begin{tabular}{|c|c|c|c|}
\hline RNA preparations & OD: $60 \mathrm{~m} / \mathrm{t}$ & $\operatorname{cpm} / \mathrm{ml}$ & $\begin{array}{c}\text { Specific } \\
\text { radioactivity } \\
\left(\mathrm{cpm} / \mathrm{OD}_{260 \mathrm{~m} \mu}\right)\end{array}$ \\
\hline Sonicates & - & 33230 & - \\
\hline Phenol-treated & 4.47 & 14900 & $3.15 \times 10^{3}$ \\
\hline $\begin{array}{l}\text { Methoxyethanol- } \\
\text { treated }\end{array}$ & 2.13 & 10300 & $4.46 \times 10^{3}$ \\
\hline Ethanol-precipitated & 1.55 & 8370 & $4.88 \times 10^{3}$ \\
\hline RNase I-treated* & - & 780 & - \\
\hline
\end{tabular}

* Ethanol-precipitated RNA solution was incubated with $1 \mu \mathrm{g} / \mathrm{ml}$ of pancreatic ribonuclease $\mathrm{I}$ at $30^{\circ} \mathrm{C}$ for $15 \mathrm{~min}$ and radioactivity remaining in the acidprecipitable fraction was measured.

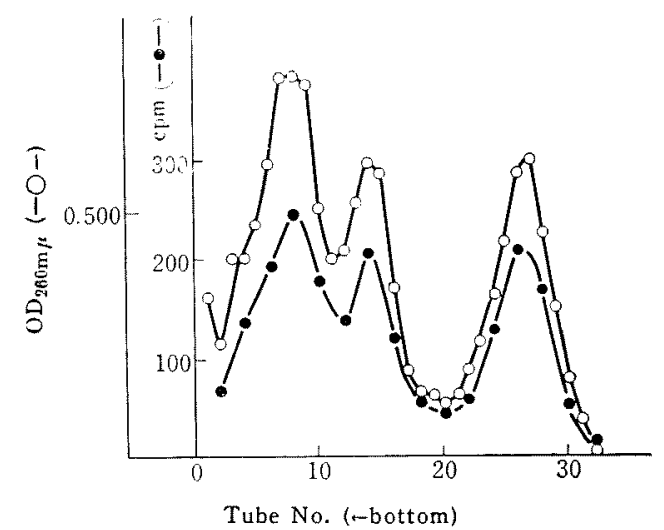

FIG. 3. Zonal Centrifugation of the Labeled RNA.
sRNA. Distribution of radioactivity coincides almost completely with the peaks of optical density (Fig. 3).

From these results, it was concluded that RNA was labeled during the incubation with tritiated angustmycin C.

Identification of angustmycin $\mathrm{C}$ residue in. corporated into RNA

Since tritiated angustmycin $\mathrm{C}$ has radioactivity in both adenine and sugar moieties, exchanging reaction of its adenine moiety with normal adenine nucleotides in the cell may result in labeling of nucleic acid without direct incorporation of angustmycin $\mathrm{C}$ as a whole. To confirm the incoporation of angustmycin $\mathrm{C}$ with its unusual sugar moiety into nucleic acid, recovery of the antibiotic from hydrolyzates of the labeled RNA was tried.

Purified RNA preparations were hydrolyzed by treatment with $0.4 \mathrm{~N} \mathrm{KOH}$ at $37^{\circ} \mathrm{C}$ for $15 \mathrm{hr}$ and the neutralized hydrolyzate was applied on a column of Dowex-1 (formate), which was eluted by gradient concentration of formic acid. Distribution of radioactivities with elution pattern of nucleosides and nucleotides in the hydrolyzate is shown in Fig. 4. Large amounts of radioactivity appeared in

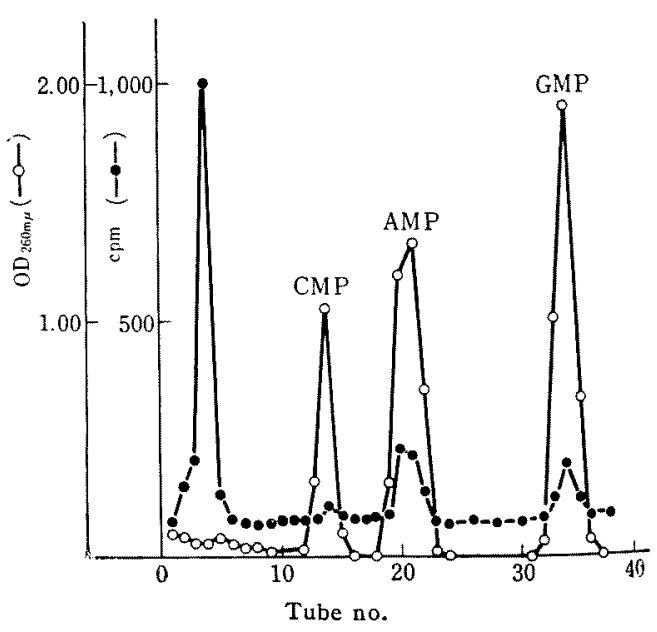

FIG. 4. Dowex-1 (formate) Chromatography of the Alkaline Hydrolyzate of the Labeled RNA. 
the nucleosides fraction, but significant activities were also found with adenylic and guanylic acids. When the nucleosides fractions were collected and applied on paperchromatography with carrier angustmycin $\mathrm{C}$ and adenosine, almost all radioactivities were found to be present not at the spots of these two nucleosides but at the region having slight lower $R f$ value than angustmycin C. Although exact nature of this compound was not identified, it was observed that the alkaline treatment of tritiated angustmycin $\mathrm{C}$ solution resulted in conversion of angustmycin $\mathrm{C}$ to the similar compound by about 30\%. This suggests that the compound may be a degra-
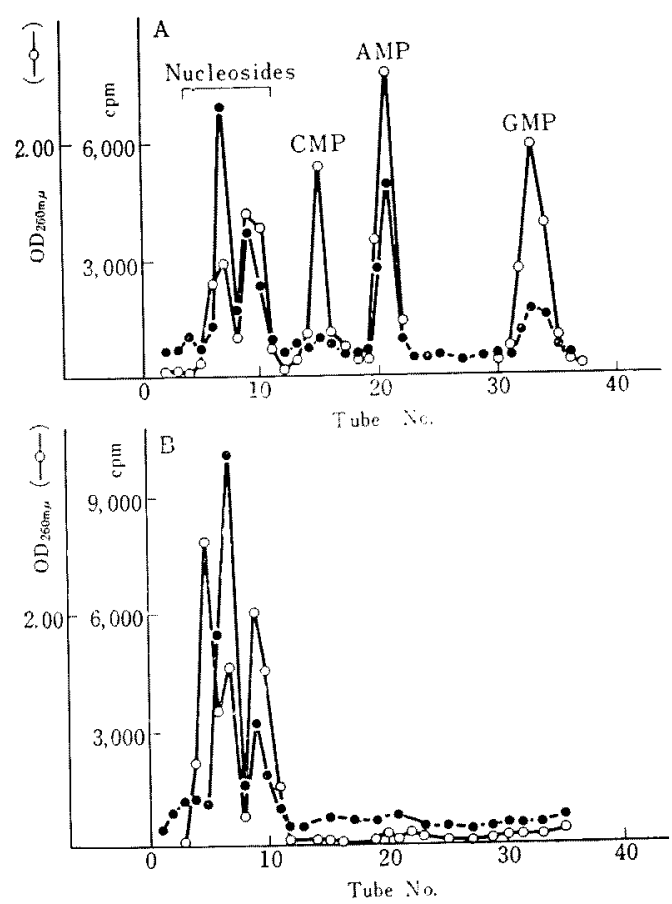

FIG. 5. Dowex-1 Chromatography of the Enzymatic Hydrolyzates of the Labeled RNA.

(A) Hydrolyzate of the RNA by pancreatic RNase I+spleen phosphodiesterase. (B) Hydrolyzate by pancreatic RNase $1+$ snake venom alkaline phosphatase.

$$
\begin{aligned}
& -\mathrm{O}-\mathrm{OD} \\
& -\mathrm{O}-\mathrm{cpm} \\
& \mathbf{c}
\end{aligned}
$$

dation product of the antibiotic incorporated in RNA under the alkaline condition.

Enzymatic hydrolysis of purified RNA was also carried out. By hydrolysis with pancreatic ribonuclease I and calf spleen phosphodiesterase at $30^{\circ} \mathrm{C}$ for $15 \mathrm{hr}$, large amounts $(58,6)$ of radioactivity appeared in the nucleoside fraction (Fig. 5A). Considerable amounts of radioactivity were also found in adenylic and guanylic acids. When the hydrolysis was carried out by the enzyme mixture of snake venom, intestinal alkaline phosphatase and pancreatic ribonuclease $I$, almost all radioactivities were found in two nucleosidic peaks (Fig. 5B). By paper chromatography of the main peak of radioactivity with carrier adenosine and angustmycin C, about $80 \%$ of radioactivity of the peak was found in the spot of angustymcin C (Table III). These data confirmed that the antibiotic was incorporated in RNA of $E$. coli cells not only by the exchanging reaction of adenine moiety but also by some incorporating system of the antibiotic as a whole.

TABLE III. DISTRIBUtION OF RADIOACTIVITY IN THE ENZYME HYDROLYZATE OF THE RNA BY The Mixture of Pancreatic RNASE, SNAKE Venom and AlKaline Phosphatase

Tube Nos. 6 and 7 in the chromatograph of Fig. $5 \mathrm{~B}$ were neutralyzed with dilute $\left(\mathrm{NH}_{4}\right) \mathrm{OH}$ and concentrated in vacuo. The sample was mixed with carrier angustmycin $\mathrm{C}$ and adenosine and spotted on filter paper (Total radioactivity spotted was about $8000 \mathrm{cpm})$. After development, each spot was extracted with water and counted.

\begin{tabular}{lrr} 
Spots counted & cpm & \multicolumn{1}{c}{} \\
Origin & 1050 & 15.5 \\
Angustmycin C & 3050 & 78.5 \\
Adenosine & 390 & 6.0
\end{tabular}

\section{DISCUSSION}

Although angustmycin $\mathrm{C}$ could not be recovered from the alkaline hydrolyzate of the RNA, it was found in the enzymatic hydrolyzates obtained under the more mild condition. From the results using snake venom, 
pancreatic ribonulease $I$ and alkaline phosphatase, recovery of angustmycin $\mathrm{C}$ was calculated to be $54 \%$ of the total radioactivity in the RNA. With the data presented in Table I, the amount of angustmycin $\mathrm{C}$ incorporated in RNA was calculated to be about $0.11 \mu$ moles per mg RNA. If angustmycin $\mathrm{C}$ replaces adenine nucleotide in polyribonuleotide chains, replacement ratio becomes about $0.016 \%$. This is a very low value comparing with those of various base analogues (for instance, 8-azaguanine was reported to replace almost $40 \%$ of guanine in RNA in Bacillus cereus under appropriate conditions ${ }^{14}$ ), but comparable with the incorporation of $1-\hat{\beta}$-D-arabinosylcytosine reported in leukemic cells. ${ }^{2} \quad$ The considerable lower value of replacement ratio of angustmycin $\mathrm{C}$ may be partially due to its potent inhibitory effect on RNA synthesis.

The fact that large amounts of radioactivity in the labeled RNA were found in nucleoside fraction after hydrolyzing RNA by alkali or enzymes (calf spleen phosphodiesterase + pancreatic ribonuclease) seemed to suggest terminal

14) J. D. Smith and R. E. F. Matthews, Biochem. J. 66, 323 (1957). location of incorporated angustmycin C. In order to confirm this point, the labeled RNA was hydrolyzed by exohydrolytic nucleases, i.e., spleen phosphodiesterase and snake venom phosphodiesterase respectively, but any selective releasing of radioactivity located at $3^{\prime}$. or $5^{\prime}$ - end could not be observed with both enzymes. In order to elucidate this apparent discrepancy concerning location of incorporated label, more precise knowledge on the linkages concerning incorporated angustmycin $\mathrm{C}$ must be needed.

Although formation of abnormal nucleic acids containing angustmycin $\mathrm{C}$ seems interesting, functional defect of RNA containing the antibiotic is not yet confirmed in vitro experiments. The fact that angustmycin $\mathrm{C}$ is incorporated into RNA suggests the presence of some activation enzymes forming angustmycin C phosphate in E. coli cells. It seems also reasonable to assume that such abnormal nucleotide formed in the cells may survive for considerably longer period after removal of the antibiotic from the medium and cause the residual inhibitory effect on $\beta$-galactosidase synthesis. 